\title{
EVALUATION OF THE CONCENTRATIONS OF PRODUCTS OF NITRIC OXIDE OXIDATION AND SOME ANTIOXIDANT VITAMINS IN SHEEP NATURALLY INFESTED WITH PARASITES
}

\author{
F.A. OSMAN* and HODA I.M. GAEDE** \\ * Parasitological unit, Animal Health Research Institute, New-Valley Lab branch. Email, \\ fathyosman14@yahoo.com \\ ** Biochemistry unite, Animal Health Research institute, Assuit Lab branch. Email, \\ hodagadee@yahoo.com
}

\section{ABSTRACT}

Received at: $29 / 5 / 2012$

Accepted:
The aim of the present study was to investigate the status of nitric oxide oxidation products and some antioxidant vitamins in sheep naturally infected with parasites. The present study was carried on 40 sheep naturally infected with parasites and 10 healthy sheep served as control, Fecal examination of naturally infected group revealed the presence of, Nematodirus. Spp, Fasciola. Spp and Trichostrogylidea eggs and Eiemira. Spp oocyst. The mean fecal egg count (FEC) in sheep infected with Trichostrongylide nematode was 5600/g and 3900/g with Eiemira. Spp oocyst. There were no blood parasite found in blood smear. The concentration of nitric oxide and antioxidant vitamins $(\mathrm{C}, \mathrm{E}, \beta$-Carotene and retinol) were determined spectrophotometrically by chemical kits in the serum of sheep under study. The results revealed that nitric oxide was significantly increased in diseased sheep than in control one $(9.01 \pm 5.6 \mu \mathrm{g} / \mathrm{ml}$ nitrate, $2.62 \pm 1.7$ nitrite and $4.60 \pm 2.32 \mu \mathrm{g} / \mathrm{ml}$ nitrate, $1.54 \pm 1.4$ nitrite $\mu \mathrm{g} / \mathrm{ml}$ respectively), while vitamin $\mathrm{E}$, revealed significant decrease in infested sheep $(0.61 \pm 0.167 \mu \mathrm{g} / \mathrm{ml}, 0.79 \pm 0.159 \mu \mathrm{g} / \mathrm{ml}$ respectively) also vitamin $\mathrm{C}$ reveled significant decrease in parasites infested group than control group $(0.092 \pm 0.042 \mu \mathrm{g} / \mathrm{ml}$ and $0.126 \pm 0.037$ $\mu \mathrm{g} / \mathrm{ml})$ on the other hand retinol and B-carotene did not significantly change in both group. It could be concluded that nitric oxide in blood serum of the infested sheep was higher than healthy control sheep $(\mathrm{p}<0.05)$, where vitamin $\mathrm{E}$ and $\mathrm{C}$ level in serum of the infected group were lower than the control group $(p<0.05)$, while the concentration of other parameters examined were not statistically different in the two groups.

Key words : Sheep-Sialic acid-Antioxidant vitamin-Parasites-Parasitological analysis

\section{INTRODUCTION}

Sheep represent an important part of the agricultural economy in Egypt where they are mostly reared in groups under harsh socioeconomic condition leading to low productive and reproductive performance. Production potential of livestock development programs is plagued in tropical and subtropical areas due to prevalence of helminthes which cause high mortality and great economic losses, (Al-Quaisy et al., 1987). Common parasites of sheep and goats include, coccidia, round worms, tapeworms and liver flukes (Bagly, 1997). Parasitic infestation represents an important cause of direct and indirect losses in farm animals, where end parasite causes significant economic losses and health problem. Fascioliasis caused by liver fluke species of the genus Fasciola has always been well recognized because of its high veterinary impact (Mostafa, 2000 and Mas-Coma et al., 2009). Parasitism in sheep and goat is a substantial problem plaguing farmers across the nation. As gastrointestinal parasite infection is the most important limiting factor of sheep productivity and parasitism has a highly detrimental effect on the sheep industry, (Jones, 2001). The blood sucking parasite Haemonchus. Controtus which is found in the abomasums of sheep and goat causes significant blood losses (Urquhart et al., 1987) 
resulting in a decrease in erythrocytes, lymphocytes, hemoglobin, body weight and wool growth, (Russel et al., 1995 and Hayat and Hussein, 1996). There are important changes in biochemistry of hosts suffering from parasitic infestation depending on the species of the parasites and sites of the host they invade (Russel and McDowell, 1989; Ozer et al., 1995).

Gastrointestinal parasites in sheep causes anemia by decreasing the amount of hemoglobin and numbers of erythrocytes, (Ozer et al., 1995). Nitric oxide is biological mediator in biochemical reactions and physiologically it is synthesized from the oxidation of L-arginine to L-citrulline, (Oswald and James, 1996). In the host the levels of nitric oxide arise in some pathologic situation where the nitric oxide is oxidized to nitric oxide 2 and nitric oxide 3 within very short time, this short duration in the conversion of nitric oxide to nitric oxide 2 and nitric oxide 3 makes it difficult to accurately measure the concentration of nitric oxide (NO). Therefore by determination of the amounts of nitric oxide 2 and nitric oxide 3 the level of nitric oxide can be assessed, (Torreilles and Guyerin, 1995). Nitric oxide (NO) is produced by a number of different cell types in an inflammatory response to cytokine stimulation by three enzymes called nitric oxide synthesis, inducible (iNOS), endothelial (eNOS) and neural (n NOS). The latter two are active in endothelial and neuron cell while (iNOS) action can be induced in status like inflammation, (Frastell et al., 1991). James, (1995) reported that nitric oxide play an important role in immunologically mediated protection against growing list of protozoan and helminthes parasites, both in vitro and in animal models. In addition to Rivero, (2006). recorded that nitric oxide excretes an important selective pressure on parasites. Vitamins are essential to health and must be supplied by food worldwide. Vitamins deficiency still result in death either directly or by reducing resistance to disease. Antioxidant vitamins such as E,C and A, protected the cells from damage by the free oxygen radicals generated by parasites, (Medzyavichyus et al., 1989), also Russel and McDowell (1989). recorded that these vitamins have a protective role on the liver.

\section{MATERIALS and METHODS}

\section{Animals}

The study was carried on 50 female non pregnant sheep (Weight 30-45 kg- aged 4-5 year old). Sheep were obtained from villages in Assuit city, Egypt, between October 2010 and October 2011. All sheep were field grazed. Forty of sheep were naturally infected with parasite while the rest (10 sheep) were clinically and laboratory healthy and used as a control group. This control group was treated with anti parasitic agent (Albendazole+Rofoxanide) twice at one week interval. Fifteen days following the last treatment sheep were parasitologically examined to indicate that animals were free from any parasite.

\section{Samples:}

\section{Fecal samples:}

Fecal samples were collected directly from all sheep in clean labeled plastic bags and prepared for parasitological analysis.

\section{Blood samples:}

Two blood samples were collected from jugular vein of each studied cases as the following.

$1 \mathrm{ml}$ bloods were collected in tube containing EDTA for preparation of blood smear for parasitological examination.

$5 \mathrm{ml}$ blood were collected in centerfuge tube without anticoagulant and left to clot and centrifuged at $2000 \mathrm{rpm}$ for $30 \mathrm{~min}$ for obtaining blood serum preparation. The separated serum was a liquated and stored at $20^{\circ} \mathrm{C}$ to be used for biochemical analysis.

\section{Parasitological analysis:}

Fecal samples were obtained from sheep under study and analyzed for helminthes eggs and larvae, cysts and oocysts of protozoa by sedimentation and flotation technique (Vaida technique) according to Coles. (1986). Egg and oocysts were counted by McMaster technique (Soulsby, 1986).

Blood sample in centerfuge tubes containing anticoagulant (EDTA) for preparation of thin blood film were fixed in absolute methyl alcohol and stained with Gimsa stain and examined for microscopic detection of blood parasite and assessment of parasitism.

\section{Biochemical analysis:}

Biochemical analysis was carried out on the serum sample for estimation of nitric oxide concentration according to the modified method of Griess assay, described by Miranada et al. (2001).

Briefly, samples were depronteinized prior to assay. The serum was added to $96 \%$ cold ethanol in 1:2 (v/v) and centrifuged for $5 \mathrm{~min}$, incubation for $1 / 2 \mathrm{~h}$ at $4^{\circ} \mathrm{C}$ and the mixture centrifuged for $5 \mathrm{~min}$. The supernatants were used for Griess assay. Analysis was done in a microtitre plate where $100 \mu \mathrm{l}$ of the supernatant was mixed with vanadium chloride ( $\mathrm{VCl} 3$ ) and followed rapidly by addition of the Griess reagent and incubation at $37^{\circ} \mathrm{C}$ for $1 / 2$ hour. The absorbance was measured by a micro plate reader (Multiskan spectrum. Thermo lab systems and Finland) at 
$540 \mathrm{~nm}$. Nitrite and/nitrate concentration were calculated using $\mathrm{NaNo} 2$ standard curve.

Antioxidant vitamins (E.,C, retinol and its precursor $\beta$-carotene) were calorimetrically analyzed using chemical kits (Biodiagnostic, Egypt). where vitamin $\mathrm{A}$ and $\mathrm{B}$-caroten according to Neeld and Pearson (1963), vitamin E was estimated using the method of Desia and Machilin (1985) and vitamin C according to Jagota and Dani (1982)

\section{Statistical analysis:}

The obtained data were analyzed by Duncan test using computers software. Results were expressed as means \pm standard division and person correlation coefficient (SPSS Version12.0) was used to analyses the correlation between the data where the significance level was set as $\mathrm{p}<0.05$.

\section{RESULTS}

\section{Clinical examination:}

The clinical signs due to parasitic infestation in sheep are ranged from diarrhea, emaciation, paleness of the visible mucous membrane, rough wool and submandibular edema,

\section{Parasitological analysis results:}

The laboratory examination of fecal sample of sheep under study revealed that the studied sheep cases were infested with single or mixed infection with parasites as in table. 1, where eggs of Trichostrongylidae. spp. detected by flotation technique, oocysts of Eimeria and Dictyoculus filaria detected by Vaida technique and Fasciolia eggs detected by sedimentation technique while employing the McMaster technique for egg count revealed that the average numbers of eggs of trichostrongylidea. spp was, and oocysts of Eimeria spp were 5600/gm and3900/gm respectively

The parasitological examination of blood film revealed absence of blood parasites infection. indicated.

\section{Biochemical analysis.}

Biochemical parameters of the infested and control sheep were shown in Table, 2 and 3. The results revealed that the infected group had highly significant increase in nitrate and significant increase in nitrite as in Table, 2, but no significant change in retinol level and its precursor $\beta$-carotene in any group and there were significant decrease in vitamin $\mathrm{E}$ and $\mathrm{C}$ as in Table, 3.

Table 1: The number of sheep infested with parasite and the type of parasitic infestation.

\begin{tabular}{lcl}
\hline Localities & $\begin{array}{c}\text { Number } \\
\text { of sheep }\end{array}$ & Parasites \\
\hline Farm, 1 & 8 & $\begin{array}{l}\text { 2 sheep with(Dictycoulus filarial larvae) }+6 \text { sheep with infection } \\
\text { (Trichostryonglide type .egg) }\end{array}$ \\
\hline Farm, 2 & 8 & $\begin{array}{l}\text { 3 sheep with Nematodirus+2 sheep with Fasciola.spp }+3 \text { sheep with } \\
\text { mixed infection (Eimeria spp+ Trichostryonglide type egg) }\end{array}$ \\
\hline Farm, 3 & 8 & $\begin{array}{l}\text { 1 sheep with Dictycoulus filarial larvae+2 sheep with Eimeria spp+4 } \\
\text { sheep with Fasciola hepatica }\end{array}$ \\
\hline Farm, 4 & 8 & $\begin{array}{l}\text { 2 sheep with Fasciola spp + 6 sheep with infection (Trichostronglyide } \\
\text { type .egg ) }\end{array}$ \\
\hline Farm, 5 & 8 & $\begin{array}{l}\text { 3 sheep with Fasciola spp +2 sheep with Eimeria spp oocysts+3 sheep } \\
\text { with mixed infection (Nematodirus spp + Trichostryonglide type egg) }\end{array}$
\end{tabular}

Table 2: The level of serum Nitrate and Nitrite in parasitic infested sheep and also in control one (Mean \pm S.D).

\begin{tabular}{lcc}
\hline Parameter & Control sheep $(\mathrm{n}=10)$ & Parasitic sheep $(\mathrm{n}=40)$ \\
\hline Nitrate $(\mathrm{ug} / \mathrm{ml})$ & $4.60 \pm 2.32$ & $9.01 \pm 5.6^{* * \wedge}$ \\
\hline Nitrite $(\mathrm{ug} / \mathrm{ml})$ & $1.54 \pm 1.4$ & $2.62 \pm 1.7^{*}$ \\
\hline${ }_{\mathrm{p}}<0.05 \quad * * \mathrm{P}<0.01$ & &
\end{tabular}


Table 3: The level of serum antioxidant vitamins in both control and parasitically infested sheep (Mean \pm S.D).

\begin{tabular}{lcc}
\hline Parameters & Control sheep & Parasitic sheep \\
\hline Vitamin C $(\mu \mathrm{g} / \mathrm{ml})$ & $0.126 \pm 0.037$ & $0.092 \pm 0.042^{*}$ \\
\hline Vitamin E $(\mu \mathrm{g} / \mathrm{ml})$ & $0.79 \pm 0.159$ & $0.61 \pm 0.167^{*}$ \\
\hline$\beta$-Carotene $(\mu \mathrm{g} / \mathrm{ml})$ & $0.43 \pm 3.83$ & $0.45 \pm 7.12$ \\
\hline Retinol $(\mu \mathrm{g} / \mathrm{ml})$ & $0.076 \pm 0.013$ & $0.072 \pm 0.018$ \\
\hline$* 0.05$ & &
\end{tabular}

\section{DISCUSSION}

Sheep in the present study were under oxidative stress due to the infection by parasites. This was appear in the changes in the oxidant/antioxidant vitamins in the blood.

In a number of studies, it has been demonstrated that in the cells of hosts infected with different species of parasites, the amount of reactive oxygen radicals which cause lipid per oxidation are increased. There by causing cell and tissue damage, (Stocker et al., 1986; Smith and Bryant, 1989 and Sarin et al., 1993).

Stimulation of tissue NO production is also associated with adverse events such as the production of the potent oxidant peroxynitrite following free-radical reaction with superoxide, (Rubbo et al., 1994), is an interesting free radical gas molecule involved in numerous physiological and path physiological process. The role of nitric oxide (NO) appears controversial because a tissue dysfunction or injury could occur after inhibition of nitric oxide. However high production level of NO has been suggested as cause of tissue injury, (Bahloli et al., 2007).

Antioxidant systems comprised of vitamins have a cellular protective action against oxidative stress which lead to cellular and tissue damage as resulted of parasitic infestation, (Mishra et al.,1994 and Dede et al., 2000). In addition to that, Das et al. (1994) Saied that the parasite damage the cells which synthesis the molecules carrying the anti oxidative agents, decrease in the number of such cell is natural. Babesia spp cause oxidative degeneration in erythrocytes while Eimeria spp. cause epithelial lesions.

Gastrointestinal worms like Trichostongylidea $s p \mathrm{p}$ cause damage in the cellular lining of the gastrointestinal worm and pulmonary worm like Dictycoulous Filaria causes damage the cells of lung tissue (Mishra et al., 1994; Dede et al., 1997 and Dede et al., 2000).

In the present study sheep infested with different types of parasites showed clear change in the oxidant /antioxidant vitamins where a highly significant increase in the concentration of (NO) in sheep infected with parasite $(p<0.05)$. This result agree with .Moncada et al. (1991) and Torreilles and Guyerin, (1995) where they reported that the concentration of $\mathrm{NO}$ synthesized physiologically increase in some pathologic condition and act as a free radicals and this result may be attributed to the damage to the cells caused by parasitic invasion. In addition to that Dede et al. (2002) recorded significant increase in the concentration of nitrate in goats infected with parasites In the present study the level of serum vitamin $\mathrm{E}$ and vitamin $\mathrm{C}$ level were found to be significantly decrease in the infected sheep $(p<0.05)$ than in the control group and that agreement with Sarin et al. (1993) and Dede et al. (2002). They recorded that the hosts infected with different parasites had decrease in the concentration of vitamin $\mathrm{E}$ and vitamin C and Gameel. (1982) reported that serum vitamin $\mathrm{C}$ level decrease in sheep infected with Fasciolia spp. In addition to that Dede et al. (1997) recorded a decreased in the serum vitamin $\mathrm{C}$ in sheep infected with Trichostrongylidae spp.

In the present study no significant change in the concentration level of retinol and its precursor $\beta$-carotene between infected and control group and it agreement with Dede et al. (2002) but disagreement with Das et al. (1994) who recorded a significant decrease in vitamin $A$ in animal infected with parasite. The result of vitamin A may be attributed to that vitamin A has antioxidant activity and plays an important role in the body ability to develop an immune response to parasitic infestation where vitamin A deficient animals have impaired immune response in the parasitic infestation.

These findings indicated that the concentration of vitamin $\mathrm{E}$ and $\mathrm{C}$ is affected by the types of parasites and the hosts they invade. 


\section{CONCLUSION}

It could be concluded that the sheep infested with different types of parasite were under oxidative stress as indicated by significant increase in nitric oxide (NO) in the blood of these animals. Parasitic infestation have a direct or indirect relationship with the oxidant status of infested sheep, therefore combating of the parasite are essential request for enhancing the productivity of sheep farm.

\section{REFRANCE}

Al-Quasiy, H.H.K.; Al-Zubaidy, A.J.; Attaf, K.I. and Makkawi, T.A. (1987): The pathogencity of haemoncheosis in sheep and goat in Iraq. Clinical, parasitological and hematological finding. Vet. Parasitol. J., 24: 221-228.

Bagly (1997): Cell Extension. Veterinarian. internal parasites. Utah state university.

Bahloli, M.; Uzun, H.; Aytae, E.; Toklu, A.S.; Paksoy, M.; Durak, H. and Ipek, T. (2007): Hyperbaric oxygen (HBO) therapy after partial hepatoectomy; An experimental study on oxidative stress in rats. Scand. J. Lab. Anim. Sci., 34: 131-140.

Coles, Embert, H. (1986): Veterinary clinical pathology. $4^{\text {th }}$ ed.W.B, saunders company, Philadelphia and Londan. 116-194.

Das, B.S.; Thurnham, D.I. and Das, D.B. (1994): Plasma alpha-Tocopherol, retinol and corticoids in children with flaciparum malaria. Am. J. Clin Nutr. 64: 94-100.

Dede, S.; Bildik, A.; Deger, S.; Deger, Y. and Yur, F. (1997): Plasma vitamin $\mathrm{C}$ and ceruloplasmin levels in the sheep infected with Trichostrongylosis. Acta Paras Ture 21: 191-194.

Dede, S.; Deger, Y.; Deger, S. and Alkan, M. (2000): Determination of the status of lipid per oxidation and antioxidant in sheep infected with certain end parasites (Fasciolia sp,Trichostrongylidae $\mathrm{sp}$ and Eineria $\mathrm{sp}$ ). Acta parasite Turk. 24: 190-193.

Dede, S.; Deger, Y.; Kahramant, Deger, S.; Alkan, M. and Cemek, M. (2002): Oxidation products of nitric oxide and the concentration of antioxidant vitamins in parasitized goats. Acta. Vet. Brno. 71: 341-345.

Desia, L.D. and Machilin, L.J. (1985): Methods of vitamin Assay $4^{\text {th }}$ ed (eds,J.Augustin,B.p.Klein,D.Beker,P.B.Venu gopal). Wiley interscience publication, John, Wiley and Sons, New York, p.255.

Frastell, C.; Fratacci, M.D.; Wain, J.C.; Jone, R. and Zapol, W.M. (1991): Inhaled nitric oxide, A selective pulmonary vasodilator reversing hypoxic pulmonary vasoconstriction. circulation in awake lamb., 83: 2038-2047.

Gameel, A.A. (1982): Fasciolia hepatica, plasma ascorbic acid, plasma iron and iron-binding capacity in experimentally infected sheep. $Z$ parasiten. kde 68: 185-189.

Hayat, C.S. and Hussein, S.M. (1996): Effect of parasitic nematodes on haematogical and productivity of sheep. Pok. Vet. J., 16: 81-83.

Jagota, S.K. and Dani, H.M. (1982): A new calometric technique for estimation of vitamin c using folin phenol reagent. Anal. Biochem, 127-178.

James, S.L. (1995): Role of nitric oxide in parasitic infections, Microbial. Rev., 59: 533-547.

Jones, R. (2001): Sheep parasites and disease. http // www. Kt. iger. bbsrc, ac.uk/FACT 20\%, sheet 20\% PDF20\% files $1 \mathrm{kt} 36 \mathrm{pdf} . \mathrm{p} 2$.

Mas-Coma, S.; Valero, M.A. and Bargues, M.D. (2009): Fasciola, Lymnaids and human Fascioliasis with global overview, evolutionary genetics, molecular epidemiology and control, Adv. Parasitol., 69: 41-146 chapter 2.

Medzyavichyus, A.K.; Bebravichyus, V.Y.; Drebitskene, G.A. and Mazalene, E.E. (1989): Effect of vitamin $\mathrm{A}$ and $\mathrm{C}$ an immunity to trichuriasis in piglets under industrial farming conditions. Acta parasitol. Lituan, 23: 115-129.

Miranada, K.M.; Espey, M.G. and Wink, D.A. (2001): A rapid simple spectrophotometer method for simultaneous detection of nitrate and nitrite. Nitric Oxide. Biol. Chem, 5: 62-71.

Mishra, N.C.; Kabilan, L. and Sharma, A. (1994): Oxidative stress and malariainfected erythrocytes. Ind. J. Malarial, 31: 77-87.

Moncada, S.; Palmer, R.M.J. and Higgs, E.A. (1991): Nitric oxide ;physiology. path physiology and pharmacology. Pharmacia Rev. 43: 109-142.

Mostafa, D. (2000): Effect of helminthes parasites on the reproductive pattern of farm and experimental animals .ph. D. Vet. Thesis (parasitological). Cairo univ., Egypt.

Neeld, J.B. and Pearson, W.N. (1963): Macro and micro methods for determination of serum vitamin A using trifluoracetic acid. J. Nutr, 79: 454-462.

Oswald, I.P. and James, S.L. (1996): Nitric oxide in host defense against parasites, Methods, 10: 8-14. 
Ozer, E.; Yilmaz, K.; Erkal, N.; Saki, C.E.; Turan, T.; Anagin, M. and Ozturk, G. (1995): Iron and iron -binding capacity of male Akkaraman sheep, experimentally infected with certain Eimiria sp, FusagBilEns derg, 9: 245-257.

Rivero, A. (2006): Nitric oxide as anti parasitic molecule of invertebrates. Trends parasitol, 22: 219-225.

Rubbo Radir, H.; Trujillo, N.; Telleri, R.; Kalyanaraman, B.; Barnes, S.; Kirk, M. and Freeman, B.A. (1994): Nitric oxide regulation of superoxide and peroxynitrite dependent lipid per oxidation. Formation of novel nitrogen containing oxidized lipid derivatives. J. Biol. Chem; 269: 2606626075.

Russel, L. and Mc Dowell, J. (1989): Vitamins in animal nutrition, Academic press inc, son Diego, California $92 \mathrm{p}$.

Russel, G.Z; Iqbal, M.; Nisar, K. and Hayate, B.(1995): 'Hematological disturbance associated with haemonchus in sheep, pok. Vet. J. 15(4): 159-162.

Sarin, K.; Kumar, A.; Prskash, A. and Sharma, A. (1993): Oxidative stress and antioxidant defense mechanism in plasmodium vivax malaria before and after chloroquine treatment. Indian. J. Malarial., 30: 127-133.

Smith, N.C. and Bryant, C. (1989): Free radical generation during primary infection with Nippostrongylus brasillients. Parasit. immunol. J. 11: 147-160.

Soulsby, E.J.L. (1986): Helminthes, Arthropods and Protozoa of domestic animals. 7ed Blackwell. scientific publication.

Stocker, R.; Hunt, N.H. and Wiedemann, M.J. (1986): Antioxidants in plasma from mice infected with plasmodium vinckei. Biochem Biophys Res commum; 134: 152-158.

Torreilles, J. and Guyerin, M.G. (1995): Does nitric oxide stress exist C. Rsearces soc Biol, Fil 189: 389-400.

Urquhart, G.M.; Armour, J.; Duncan, L.; Dunn, A.M. and jenning, F.W. (1987): Veterinary parasitology. Longman group U.K, LTD, England, pp; 19: 276277.

\section{تقيم تركيز اوكسيد النيتريك الناتج من الاكسدة وبعض الفيتامينات المضادة للاكسدة فى الاغنام المصابة بالطفيليات فتحى احد عثمان ، هلى ابراهيم مصطفى جعبإى}

استهدفت الدر اسـة فحص مستوى اكسيد النيتريك (نـاتج الاكسدة) وبعض الفيتامينات المضادة للاكسدة فى الاغنـام المصابة طبيعيا

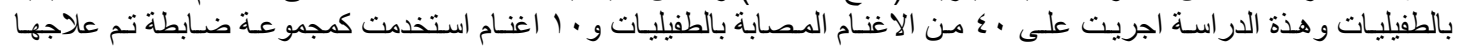

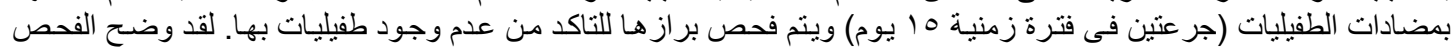

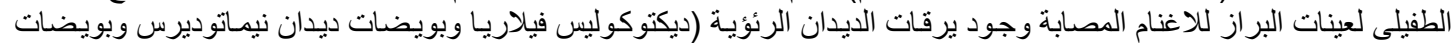

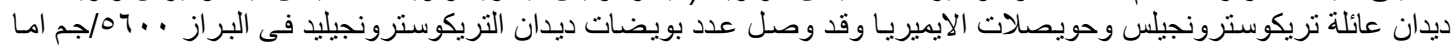

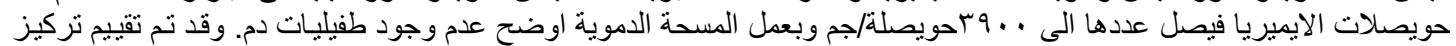

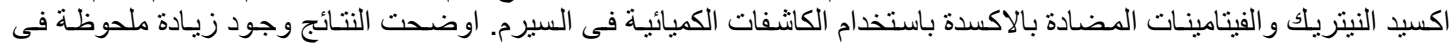

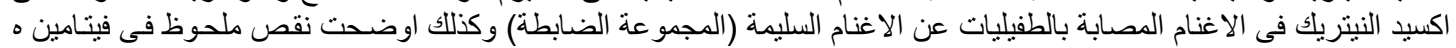

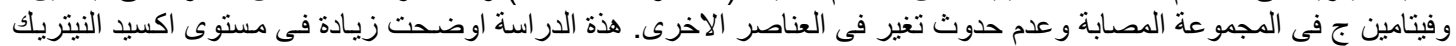

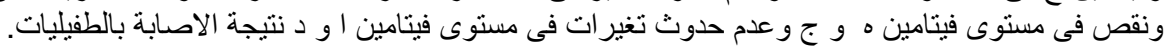

